\title{
細菌性前立腺炎の発症に関する臨床細菌学的研究
}

\author{
II. 前立腺炎由来 E. coli の病原性因子 \\ 岡山大学泌尿器科学教室（主任：大森弘之教授） \\ 山田大介
}

\section{CLINICO-BACTERIOLOGICAL STUDIES ON THE ETIOLOGY OF BACTERIAL PROSTATITIS}

II. Virulence Factors of E. coli in Bacterial Prostatitis

\author{
Daisuke Yamada \\ Department of Urology, Okayama University Medical School \\ (Director: Prof. Hiroyuki Ohmori)
}

The virulence factors of $E$. coli in bacterial prostatitis were studied using 59 E. coli isolated from uncomplicated prostatitis.

O-antigens of prostatitis-derived $E$. coli belonged to some specific serotypes such as $0 \sim 4,6,18,22$ and the haemolysin production was positive in $64.4 \%$. With regard to the fimbriae, the majority of the strains had type 1 fimbriae (81.4\%).

Mannose resistant (MR) fimbriae were also positive in $59.3 \%$ and both type 1 and MR fimbriae were positive in $55.9 \%$. Among MR strains, P-fimbriated and S-fimbriated strains were present in $25.7 \%$ and $28.6 \%$, respectively, indicating that these two MR fimbriae were not always specific for the prostatitis-derived E. coli. Although the specific adhesion of $E$. coli onto the human prostatic epithelium mediated by MR-fimbriae was equivocal, that mediated by type 1 fimbriae was observed clearly. Therefore, type 1 fimbriae was thought to be one of the most significant virulence factors in the pathogenesis of prostatitis caused by $E$. coli.

Key words: bacterial prostatitis, $E$. coli, fimbriae

要旨：細菌性前立腺炎における E. coli の病原性因子を解析するために, 下部尿路に基礎疾患のない急性 細菌性前立腺炎患者由来 E. coli 59株の in vitroでの各種性状ならびに前立腺組織への付着性について検 討した.

1）前立腺炎由来 $E$. coli は O- 4，6，18，22等の特定の血清型に偏っており， haemolysin 産生能を 有するものが $64.4 \% を$ 占めていた。

2）Type 1 線毛の保有率が $81.4 \%$, MR 線毛の保有率が $59.3 \%$ と高く, 両者を共に有する株が $55.9 \%$ と 約半数を占めた.

3） $\mathrm{MR}$ 線毛の内 $\mathrm{P}$ 線毛の占める割合は $25.7 \%, \mathrm{~S}$ 線毛の占める割合は $28.6 \%$ でり，必ずしも前立腺 由来株に特異的な線毛とは言えなかった。

4）前立腺腺腔上皮細胞への付着に関しては, MR 線毛を介するものは不明確であったが, type 1 線毛 を介する特異的付着が認められた。したがって, 前立腺炎に抢ける E. coli の病原性は type 1 線毛を中心 に発現される可能性が示唆された。

キーワード：細菌性前立腺炎, 大腸菌, 線毛

\section{緒 言}

一般に，細菌感染症は病原性細菌と宿主との相互関 係に掞いて成立するものであり，基礎疾患のない患者 における単純性感染症の成立には細菌自体の病原性因
子が強く関与するものと考兄られる，単純性尿路感染 症の主要原因菌であるE. coli に関しては, 尿路病原性 E. coli として種々の検討12) がなされ，最近では感染症 発症の第 1 段階としての付着・定着機構がその病原性 
因子の一つとして注目されている3 ${ }^{3)}$. 細菌の臓器へ の付着・定着には細菌の線毛が深く関与しており，E. coliの線毛の性状とその臓器特異性についても報 告6) 99がなされている.一方, 前報10)にて報告したよう に，明らかな尿路の基礎疾患がない男性に発症する急 性細菌性前立腺炎の大半が腸管外 E. coli 感染症であ り，その発症に際しては，E. coli の病原性因子が深く 関与しているものと容易に想像できる。しかし，現在 までに前立腺炎由来 E. coli に打ける付着・定着因子を 含めた病原性因子に関するまとまった報告はほとんど なされていない。

今回著者は, 尿路に基礎疾患のない急性細菌性前立 腺炎患者由来 E. coli 59株を用いて, 前立腺炎の発症に 拈ける E. coli の病原性因子について線毛を中心に検 討を加えた。

\section{対象および方法}

\section{1. 試験菌}

前立腺炎由来 $E$. coli の病原性因子検討のための試 験菌は, 岡山大学医学部泌尿器科および当科関連病院 を受診した急性細菌性前立腺炎患者, 寸なわち, 発熱, 排尿痛, 前立腺腫脹等の明らかな急性症状を有し， か つ，下部尿路に明らかな基礎疾患の無い患者より得ら れた E. coli 計59株を用いた。

2. 前立腺炎由来 $E$. coli の性状

1) $\mathrm{O}$ 抗原血清型別

O- $1,2,4,6,7,8,11,14,16,18,22$, $25,62,75$ の 14 種類の抗血清 (国立予防衛生研究所, 細菌学部より分与）を用いて 0 抗原を判定した。

\section{2）各種線毛の検出}

那須の方法 ${ }^{21}$ に従いマンノース感受性凝集 (MSHA), 非感受性凝集（MR-HA）を判定するとともに, MR-HA 陽性の株については P 線毛, および $\mathrm{S}$ 線毛の 検出を試みた。 $\mathrm{P}$ 線毛の検出はグロボシド含有リポ ソーム凝集法 ${ }^{3}$, S 線毛の検出は, Parkkinenn らの方 法 ${ }^{11}$ に従いMR-HA 陽性株の血球凝集がノイラミニ ダーゼ処理赤血球でも認められるか否かをもって判定 した.

\section{3) Haemolysin 産生能}

$5 \%$ ヒッジ血液平板を用い, 溶血の有無をもって産 生株, 非産生株を判定した。

\section{3. 前立腺組織への付着実験}

前立腺肥大症手術患者での摘出前立腺組織, および 慢性前立腺炎患者での経会陰的前立腺生検組織のう ち, HE 染色にて組織学的に明らかな異常を認めな かった部位を用いて，in vitroにおける前立腺炎由来 E. coli のヒト前立腺組織への付着実験を行なった.

組織は periodate-lysine-paraformaldehyde (PLP) 液を用い $4{ }^{\circ} \mathrm{C}$ で一夜固定し，10\%，15\%，20\%と徐々 に含有 sucrose 濃度を上げたPBS 液にて順次洗浄後 OCT コンパウンドにて包埋凍結し，TISSUE-TEK II (LAB-TEK) にて厚さ $4 \mu \mathrm{m}$ の凍結切片を作成, PBS で 2 回洗浄後付着実験に供した. 付着実験は那須の方 法6) に従い, 菌体浮遊液と等量の PBS 或いは $6 \%(\mathrm{~W} /$ V)D-mannose 加 PBS の混合液中で, 振盪下に $4{ }^{\circ} \mathrm{C} て ゙$ 1 時間反応させた。菌の付着はPBSにて 3 回洗浄後, 間接蛍光抗体法にて観察した。すなわち, 一次抗体と してE. coliの 0 抗原血清型別用ウサギ血清（10倍希 釈)を室温で30分間, 次いで, 正常ヤギ血清（20倍希 釈）を室温で30分間, その後, 二次抗体として, 抗ウ サギ IgG・FITC 標識ヤギ F $\left(\mathrm{ab}^{\prime}\right)_{2}$ (JACKSON IMMUNORESEARCH LABORATORIES, USA) (50 倍希釈)を室温で30分間反応させた。な挆試験菌は in vitro での性状が安定している OEP-95, 369, 406, 432, 141の 5 株を用いた。

\section{結果}

1. 前立腺炎由来 $E$. coli の各種性状

1) $O$ 抗原血清型別

今回使用した 14 種の抗血清にて59株中52株(88.1\%) の型別の決定が可能であり，なかでも O- 1，2，4， $6,18 ， 22 ， 25 ， 75$ 等の特定の血清型に偏っていた. 特にO- $4 ， 6 ， 18 ， 22$ はそれぞれ 9 株 $(15.3 \%) ， 6$ 株

Table 10 antigen distribution of $E$. coli isolated from cases of ABP, AUP and AUC and from faecal samples

\begin{tabular}{c|c|c|r|c}
\hline & $\begin{array}{c}\text { ABP } \\
\text { (59 strains) }\end{array}$ & $\begin{array}{c}\text { AUP } \\
(47 \text { strains })\end{array}$ & $\begin{array}{c}\text { AUC } \\
(183 \text { strains })\end{array}$ & $\begin{array}{c}\text { Faecal samples } \\
\text { (59 strains) }\end{array}$ \\
\hline $0-1$ & $4(6.8)$ & $5(10.6)$ & $13(7.1)$ & 0 \\
2 & $4(6.8)$ & $5(10.6)$ & $8(4.4)$ & $1(1.7)$ \\
4 & $9(15.3)$ & $1(2.1)$ & $13(7.1)$ & 0 \\
6 & $6(10.2)$ & $13(27.7)$ & $24(13.1)$ & $6(10.2)$ \\
7 & & & $7(3.8)$ & $1(1.7)$ \\
8 & $1(1.7)$ & $2(4.3)$ & $2(1.1)$ & 0 \\
14 & $1(1.7)$ & & & 0 \\
16 & $2(3.4)$ & $5(10.6)$ & $20(10.9)$ & 0 \\
18 & $11(18.6)$ & $3(6.4)$ & $25(13.7)$ & 0 \\
22 & $7(11.9)$ & $2(4.3)$ & $11(6.0)$ & 0 \\
25 & $4(6.8)$ & $2(4.3)$ & $7(3.8)$ & $2(3.4)$ \\
75 & $3(5.1)$ & $4(8.5)$ & $23(12.6)$ & $3(5.0)$ \\
Typable & $52(88.1)$ & $42(89.4)$ & $153(83.6)$ & $13(22.0)$ \\
\hline
\end{tabular}


(10.2\%)，11株 (18.6\%)， 7 株 (11.9\%) と $10 \%$ 以上 を占め, その 4 種の血清型で血清型別の決定が可能で あった 52 株中 33 株 $(63.5 \%)$ を占めていた。な打比較 のため教室の那須 ${ }^{2}$ が検討した急性単純性膀脱炎 (AUC)，急性単純性腎孟腎炎 (AUP), 及び䔬便由来 株についての検討結果も共に示した（Table 1).

2）線毛の性状

前立腺炎由来 E. coli 59株の線毛の性状を, 先に検討 した O 抗原と組み合せて Table 2(a)，(b)に示した。

MS (type 1) 線毛のみを有する株は15株 (25.4\%), MR 線毛のみを有する株は 2 株 (3.4\%) であるのに対 し，MS 及び MR 線毛を共に有する株は33株(55.9\%) であった，MR 線毛を有する35株の内 $\mathrm{P}$ 線毛は 9 株 (25.7\%), S 線毛は10株 (28.6\%) と必ずしも多数では なかったが，P 及び S 線毛保有株は全て type 1線毛を
保有しており，これらの MR 線毛と type 1線毛との連 関が示唆された。また，O抗原との関係についてみる と, O- 4，6，18，22の主要な血清型に属する株は S 線 毛では 10 株中 8 株, $\mathrm{P}$ 線毛では 9 株中 2 株であり, $\mathrm{S}$ 線 毛は $\mathrm{P}$ 線毛に比べ有意 $\left(\mathrm{p}<0.05 ： \chi^{2}\right.$ test）に偏った 血清型に属していた。 また $\mathrm{P}$ 及び $\mathrm{S}$ 線毛以外の $\mathrm{MR}$ 線毛 (X 線毛) も16株中 13 株が，主要な血清型に属し て拈り, $\mathrm{P}$ 線毛に比べ有意 $\left(\mathrm{p}<0.05: \chi^{2}\right.$ test $)$ に偏っ た O抗原分布を示した。

3) Haemolysin 産生能

Haemolysin 産生能と $\mathrm{O}$ 抗原との関係を Table 3 (a),（b)に，線毛との関係をTable 4に示した。 haemolysin 産生能は, $\mathrm{O}$ 抗原と比較的密接な関連性を 示していたが，個々の血清型に属する株数が少なく統 計学的検討は行なわなかった。しかし，先に述べた O-

Table 2-(a) Relationship between 0 antigens and fimbriae in $E$. coli isolted from ABP

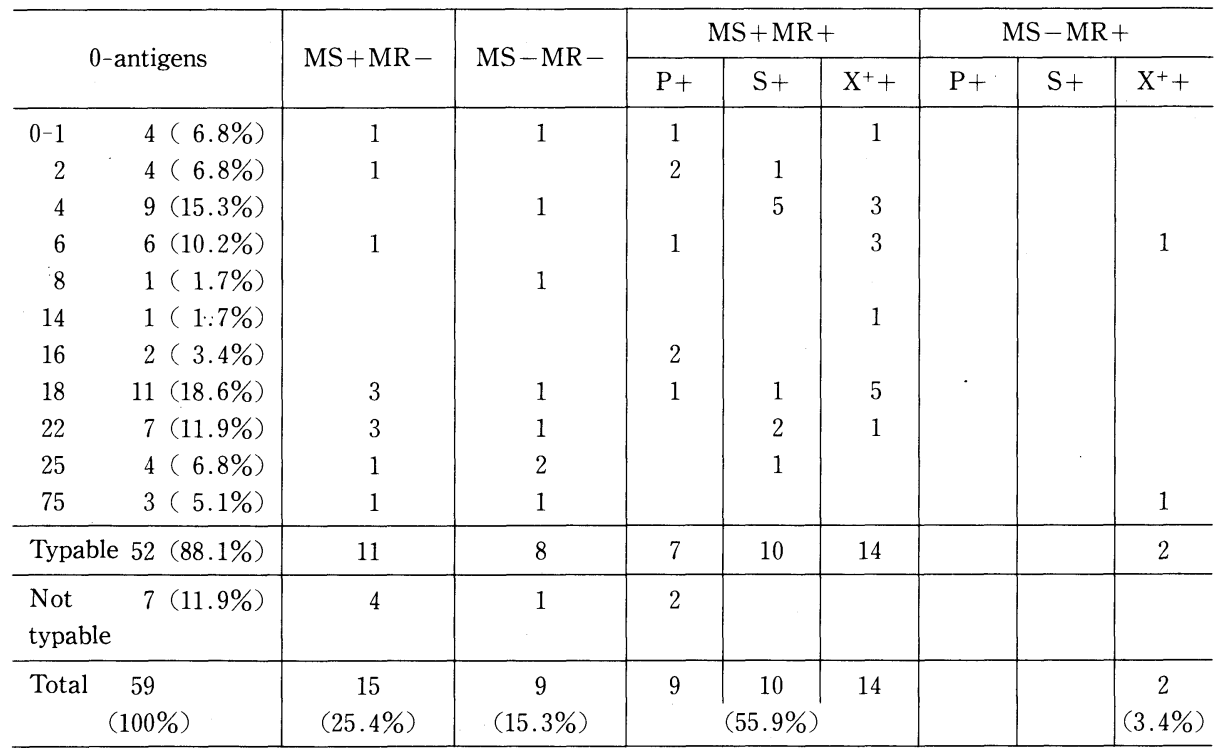

$+\mathrm{X}^{+}$means not $\mathrm{S}$ and not $\mathrm{P}$ pili

Table 2-(b) Relationship between 0 antigens and fimbriae in E. coli isolated from ABP

\begin{tabular}{|c|c|c|c|c|c|c|c|c|}
\hline \multirow{2}{*}{0 -antigens } & \multirow{2}{*}{$\mathrm{MS}+\mathrm{MR}-$} & \multirow{2}{*}{$\mathrm{MS}-\mathrm{MR}-$} & \multicolumn{3}{|c|}{$(\mathrm{MS}+\mathrm{MR}+)$} & \multicolumn{3}{|c|}{$(\mathrm{MS}-\mathrm{MR}+)$} \\
\hline & & & $\mathrm{P}+$ & $\mathrm{S}+$ & $\mathrm{X}^{+}+$ & $\mathrm{P}+$ & $\mathrm{S}+$ & $\mathrm{X}^{+}+$ \\
\hline $\begin{array}{l}\text { Major } \\
\text { sero-types } \\
(0-4,6,18,22)\end{array}$ & 7 & 3 & 2 & $\begin{array}{c}(22) \\
8\end{array}$ & 12 & & (1) & 1 \\
\hline $\begin{array}{l}\text { Other } \\
\text { sero-types }\end{array}$ & 8 & 6 & 7 & $\begin{array}{c}(11) \\
2\end{array}$ & 2 & & (1) & 1 \\
\hline
\end{tabular}

$+: \mathrm{X}^{+}$means not $\mathrm{S}$ and not $\mathrm{P}$ pili 
Table 3-(a) Relationship between 0 -antigens and haemolysin production

\begin{tabular}{c|c}
\hline 0 antigens & Haemolysin production \\
\hline $0-1$ & $1 / 4(25.0 \%)$ \\
2 & $3 / 4(75.0 \%)$ \\
4 & $7 / 9(77.8 \%)$ \\
6 & $5 / 6(83.3 \%)$ \\
8 & $0 / 1(0 \%)$ \\
14 & $0 / 1(0 \%)$ \\
16 & $1 / 2(50.0 \%)$ \\
18 & $7 / 11(63.6 \%)$ \\
22 & $7 / 7(100.0 \%)$ \\
25 & $3 / 4(75.0 \%)$ \\
75 & $0 / 3(0 \%)$ \\
\hline Subtotal & $34 / 52(65.4 \%)$ \\
\hline Not typable & $4 / 7(57.1 \%)$ \\
\hline Total & $38 / 59(64.4 \%)$ \\
\hline
\end{tabular}

Table 3-(b) Relationship between 0-antigens and haemolysin production

\begin{tabular}{|c|c|}
\hline 0 -antigens & Haemolysin production \\
\hline $\begin{array}{l}\text { Major sero-types } \\
(0-4,6,18,22)\end{array}$ & $26 / 33(78.8 \%) \longrightarrow$ \\
\hline Other sero-types & $12 / 26(46.2 \%) \square$ \\
\hline
\end{tabular}

* : $\mathrm{p}<0.05$ ( $\chi^{2}$ test $)$

Table 4 Relationship between haemolysin production and type of pili

\begin{tabular}{c|c}
\hline Type of pili & Haemolysin production \\
\hline MS + & $35 / 48(72.9 \%)-*^{*}$ \\
MS - & $3 / 11(27.3 \%)-$ \\
MR+ & $25 / 35(71.4 \%)$ \\
MR - & $13 / 24(54.2 \%)$ \\
& \\
MS + MR- & $10 / 15(66.7 \%)$ \\
MS - MR- & $3 / 9(33.3 \%)$ \\
MS + P+ & $6 / 9(66.7 \%)$ \\
MS + S+ & $9 / 10(90 \%)$ \\
MS + X + & $9 / 14(64.3 \%)$ \\
MS - X + & $1 / 2(50 \%)$ \\
\hline Total & $38 / 59(64.4 \%)$ \\
\hline
\end{tabular}

$*: \mathrm{p}<0.025\left(\chi^{2}\right.$ test $)$

$+: \mathrm{X}^{+}$means not $\mathrm{S}$ and not $\mathrm{P}$ pili

$4 ， 6 ， 18 ， 22$ 主要な血清型に属する33株と, その 他血清型に属する26株の 2 群に分けて検討すると, haemolysin 産生株は, 前者で78.8\%(26/33), 後者で
Table 5 Phase variation of fimbriae of each strains

\begin{tabular}{c|l|l}
\hline Strain & Nutrient broth & CFA agar \\
\hline OEP-95 & none & none \\
OEP-369 & type 1 & none \\
OEP-406 & type $1, \mathrm{mr}^{*}$ & MR (P) \\
OEP-432 & type $1, \mathrm{mr}^{*}$ & MR (S) \\
OEP-141 & type $1, \mathrm{mr}^{*}$ & MR $\left(\mathrm{X}^{*}\right)$ \\
\hline
\end{tabular}

$\mathrm{mr}^{*}:$ repressed phase of $\mathrm{MR}$

$\mathrm{X}^{*}$ : not $\mathrm{P}$ and not $\mathrm{S}$

$46.2 \%(12 / 26)$ であり, 前者の方の heamolysin 産生 能が有意に高率であった $\left(\mathrm{p}<0.05: \chi^{2}\right.$ test $)$. 線毛と haemolysin 産生能との関係では, type 1線毛を有する 48株中 35 株 (72.9\%) が haemolysin 産生能を有してい たが， type 1線毛を有さない11株では，3株 (27.3\%) しか haemolysin 産生能を有しておらず type 1線毛保 有株に扣ける haemolysin 産生株が有意に高率 $(\mathrm{p}<$ $0.025: \chi^{2}$ test）であった.

個々の線毛と haemolysin 産生能との関係では株数 が少なく断定的なことは言えないが，S 線毛保有株に おいて10株中 9 株と haemolysin 産生株の占める割合 が高かった。

\section{2. 前立腺組織への付着実験}

使用した E. coli 6 株の性状を Table 5 に要約し た。これらの主として phase variant株を使用し，前 立腺組織への in vitroでの付着を観察した。 その結果, nutrient broth で培養した場合, OEP-95以外の 5 株は D-mannose 非存在下で前立腺腺腔上皮へ多数の菌体 が付着したが, D-mannose 存在下では 6 株共に付着は 認めず, type 1線毛を介しての前立腺腺腔上皮細胞一 の特異的付着と考吕られた。

Fig. 1 は Nutrient broth で培養した OEP-141を用 いての D-mannose 非存在下での付着実験時の蛍光顕 微鏡写真であるが，蛍光を発する菌体が前立腺腺腔上 皮に多数付着しているのが観察される。一方 CFA agar で培養し MR 線毛を発現している phaseに括け る OEP-406, 432, 141の 3 株を用いての D-mannose 存 在下の付着実験に関しては, 使用する前立腺組織の由 来, 組織の固定条件, 実験温度, 反応時間等に左右さ れ，再現性の高い成績は得られなかった。したがって， 今回の実験結果としては，MR 線毛を介しての特異的 付着は不明確であり, $\mathrm{P}, \mathrm{S}, \mathrm{X}$ ( $\mathrm{P}, \mathrm{S}$ 以外の $\mathrm{MR}$ 線毛)の 3 種の MR 線毛間での前立腺組織への付着性の差は 確認し得なかった。 
Fig. 1 Adhesion of E. coli OEP-141 to the psostatic ducts observed by an indirect immunofluorescent method. Note numerous $E$. coli adhere to epithelial cells of the prostatic ducts. $400 \times$

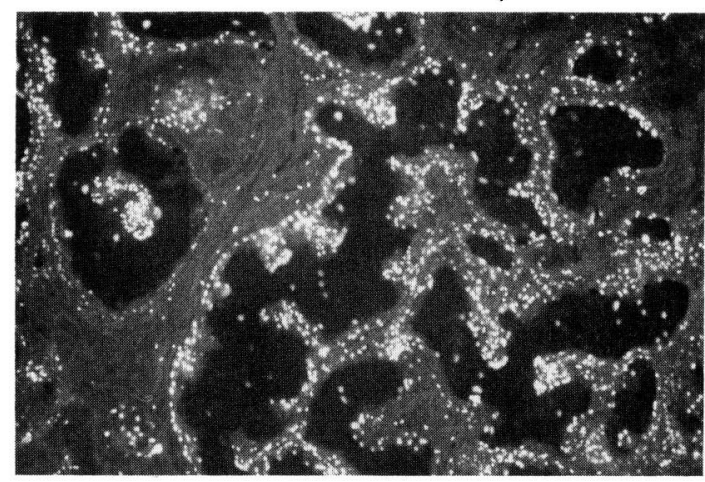

考 察

本来 E. coli は腸管内の常在菌であるが，時として， 腸管内でも病原性を示す。をた，尿路感染症，特に明 かな基礎疾患の無い尿路感染症の主要な起炎菌はその ほとんどが E. coliである ${ }^{12)}$.これらの病原性を示す $E$. coli は非病原性の E. coli と比較すると, 異なる細菌学 的性状を示すことが，近年明かにされつつある1 ${ }^{1) ~ 10) . ~}$ すなわち haemolysin 産生能, 特定の血清型別等の組 織障害性因子の存在 ${ }^{2}$, また, 標的蔵器への付着に際し ての臓器特異性を有する線毛の存在等3)6 であり, 今日 E. colikよる感染症の解析は感染症の成立と言う点 に関して，非常に興味ある感染実験系と言える。

一方，著者が行った細菌性前立腺炎に関する臨床的 検討 ${ }^{10}$ に打いて再確認されたように，急性細菌性前立 腺炎の起炎菌はその注とんどが E. coliである.全身的 に特に問題のない青壮年の男性に, 突然の高熱及び排 尿痛を主症状として発症する急性細菌性前立腺炎は， その臨床経過から考えても一般の尿路感染症における E. coli と同様，ないしそれ以上に菌体側の病原性因子 が，感染症の成立に括いて重要であると考えられる。 したがって, 前立腺炎由来の E. coli の細菌学的性状, 特に，その病原性因子を解析することは，単に前立腺 炎の発症のメカニズムのみならず細菌感染症そのもの を理解する上できわめて重要である。

1. 急性前立腺炎由来 $E$. coli の各種性状

今回の実験成績より, 前立腺炎由来 $E$. coli の $\mathrm{O}$ 抗 原分布は急性単純性膀脱炎由来のものに近く, 特にO $4 ， 6 ， 18 ， 22$ が主要な血清型であった。また haemolysin に関しては64\%が産生株であり,線毛に関 しては，81\%の株が type 1線毛を有し，MR 線毛を有 する株も59\%に存在した。これらの性状は糞便由来株 の性状と明らかに異なるものであり，急性前立腺炎も 腸管外 E. coli 感染症として, $O$ 抗原, haemolysin 産 生そして線毛といら病原性因子の存在が重要であるこ とが示唆された。

個々の因子の連関については，検討株数が59株と必 ずしも多くはなかったが，(1) MS 線毛を有する菌株で の haemolysin 産生株 (35/48：72.9\%) が非産生株 (3/ $11: 27.3 \%$ ）に比して有意に高率であること，O-4， $6 ， 18 ， 22$ 主要な血清型に属する菌株とそれ以外に 分けて考克れば，(2)前者の haemolysin 産生株（26/ $33: 78.8 \%)$ が後者 $(12 / 26 ： 46.2 \%)$ に比べ有意に多 かったこと, (3) type 1線毛，MR 線毛の保有率が前者 では33株中30株 (90.1\%)，33株中23株 (69.7\%) と高 率となること,ならびに，(4) S 及び X 線毛が P 線毛に 比べて主要な血清型に有意に多く含まれていたことな ど, これら 3 種の病原性因子間の連関を示唆する結果 と考学られた。な䑙那須は，女子の急性単純性膀胱炎 由来のE. coliでは，O-18と MS及び MR 線毛, haemolysin 産生能の 3 者間に高い連関が認められた と報告2てているが，今回の前立腺炎由来株では O-18 の11株中 haemolysin 産生株は 7 株 (63.6\%), MS+ $\mathrm{MR}+$ 株も 7 株 (63.6\%)であり，特に連関が高いとは 言えなかった。一方，今回の成績からすると，O-22 と MS 及び MR 線毛, haemolysin 産生能の 3 者間に高 い連関が認められ，臟器特異性といら点から注目され た.

ところで，今回 MR 線毛の検討においては，那須の 報告 ${ }^{3)}$ における $\mathrm{P}$ 線毛に加光 $\mathrm{S}$ 線毛についても検討を 行なっている. S 線毛はシアル酸である sialyl ( $\alpha 2-3)$ galactoside をレセプターとし11), 乳児の䯣膜资におい て重要な役割を果す可能性が示唆されている線毛であ るが，今回特に $\mathrm{S}$ 線毛に着目したのは，前立腺に打け るシアル酸産生細胞の存在があったからである。この 細胞は前立腺腺腔開口部, 精阜周辺に存在 ${ }^{13)}$ し, 解剖学 的位置関係から E. coli の付着の第 1 段階に打いてレセプ ターとなりらる可能性が十分予測された。をた, 欄ら の組織化学的検討で, 前立腺腺腔自由側がConcanavalin A (Con A), 及び Limuluspolyphemus agglutinin（LPA）などに陽性反応を示すが, Ricinus communis agglutinin (RCA) に対しては微弱陽性な いしは陰性反応しか示さないことが明かとなってい 
る.これらレクチンの糖鎖認識パターンはCon A が type 1線毛に, LPA が $\mathrm{S}$ 線毛に, RCA が P 線毛に類 似することより, 前立腺腺腔には type 1 線毛及び $\mathrm{S}$ 線 毛が付着可能であり，P線毛は付着しにくいことが予 想された。さらに, 尿中の Tamm-Horsfall 蛋白 (THGP)は S 線毛のインヒビターであることより，尿 路感染症に怙いて S 線毛の果す役割は低い15) と考兄 られるが, 前立腺の解剖学的位置関係より, $\mathrm{S}$ 線毛保有 細菌でも尿中の THGP の影響を比較的受けずに前立 腺へ到達する可能性があると考兄られた。結果的には $\mathrm{S}$ 線毛は MR 線毛を有する35株中 10 株, $28.6 \%$ 占め るに過ぎなかったが, 前立腺炎由来株に拈ける 4 種の 主要な血清型に 10 株中 8 株と, $\mathrm{P}$ 線毛に比べ有意に多 く含まれていたこと, 病原性因子のひとつである haemolyisin 産生能を有する株が10株中 9 株と高率に 存在したこと, 短期間に再然を認めた症例 ${ }^{100} の$ 起炎菌 が S 線毛保有株であったこと,さらに type 1 線毛との 連関が示唆されることなど, 急性前立腺炎由来 E. coli における S 線毛の重要性を支持する結果もあり,さら に症例数を増やして検討を加える必要があろう。

一方, P 線毛に関しては Keith 591 は急性細菌性前 立腺炎由来 E. coli 12 株中 10 株 (83.3\%) が $\mathrm{P}$ 線毛保 有株であったとし，小児に拈ける腎孟腎炎由来 E. coli 同様, 前立腺炎に打いても $\mathrm{P}$ 線毛が重要な付着性因子 であるとしているが，今回の著者の検討結果，ならび に, 先に述べた前立腺腺腔の糖鎖構造を考兄合わせれ ば前立腺炎の発症に㧍ける $\mathrm{P}$ 線毛の役割は否定的で あろう。

2. in vitro に拈ける E. coli の前立腺腺腔上皮細胞 への付着実験

那須 ${ }^{6}$ は E. coli の前立腺への付着実験において, type 1線毛を介しての付着は認められず, $\mathrm{P}$ 線毛以外 の MR 線毛を介しての付着のみを認めたと報告して おり, 前立腺に特異性を持った $\mathrm{P}$ 線毛以外の $\mathrm{MR}$ 線毛 の存在の可能性を示唆している. しかし, 今回の検討 では前立腺腺腔への E. coli の付着は type 1線毛を介 するものしか明確ではなかった。先に述べた前立腺腺 腔の糖鎖構造より, S 線毛を介する付着が期待された が, 今回は不明確であった。 したがって, 現時点では 前立腺腺腔に付着性のある線毛は type 1 線毛のみで あったが，付着実験に使用した前立腺組織が果たして 適切な部位であったか否かといら問題, 組織の固定な どの実験条件上の問題, ならびに, 現在マンノースを 認識する線毛を type 1線毛として一括しているが, 認
識するマンノース糖鎖構造の差異によりさらに細かな subtype に分れる可能性も考号られ, 今後前立腺組織 の糖鎖構造の解析, および, 分子生物学的手法を含め た E. coli の病原性因子の解析などさらに細かな検討 が必要であろう。

いずれにせよ, 前立腺炎由来 E. coli の性状は䔬便由 来株とは大きく異なって招り, 尿路由来株と同様に線 毛保有株が大多数を占め, 発症の初期段階において type 1線毛を始めとする線毛が関与する事は疑う余地 のないところであろら。また， type 1線毛と MR 線毛 の両者を保有する株が過半数を占めることから，感染 成立の各ステップに招いて発現する線毛とその病原的 意義も異なる可能性もあり, 特に MR 線毛の中では $\mathrm{S}$ 線毛を中心として，今後さらに検討が必要であると考 えられる。

\section{結 語}

急性細菌性前立腺炎由来 E. coli 59 株の細菌学的性 状を検討した。

血清型は O- 4，6，18，22の 4 種が主要な血清型で あり, haemolysin 産生能を有する株が $64 \%$ と過半数を 占めた。前立腺炎に特異的な線毛は必ずしも明らかで はなかったが, $81 \%$ の株が type 1 線毛, $59 \%$ の株が MR 線毛を保有しており，個々の病原性因子との連関も示 唆された。 さらに, type 1線毛を介しての前立腺腺腔 上皮への特異的付着が in vitroにて認められ，前立腺 炎由来 E. coli の病原性は type 1 線毛を中心に発現さ れるものと考学られた。

稿を終えるに当り, 御指導, 御校閲を頂いた恩師大森弘之 教授, 直接御指導頂いた公文裕巳講師, 適切な御助言を頂い た細菌学教室友近健一講師, 並びに, 研究遂行にあたり御協 力頂いた光畑律子，赤澤早苗技術員に深謝致します。

\section{文献}

1) Minshew, B.H., Jorgensen, J., Swanstrum, M., Grootes-reuvecamp, G.A. and Falkow, S. : Some characteristics of Escherichia coli strains isolated from extraintestinal infections of humans. J. Infect. Dis., 137, 648-654, 1978.

2) 那須良次：尿路性器感染症に扮けるE. coli の病 原性因子について. その 1 . 急性単純膀脱炎由来株 の性状. 日泌尿会誌, 79, 1162-1168, 1988.

3) 那須良次：尿路性器感染症に打ける E. coli の病 原性因子について. その $2 . \mathrm{P}$ 線毛の検出と病態と の関連性. 日泌尿会誌, 79, 1169-1176, 1988.

4) Firon, N., Ofek, I. and Sharon, N. : Interaction of mannose-containing oligosaccharides with the fimbrial lectin of Escherichia coli. Biochem. 
And biophys. Res Commun. 105, 1426-1432, 1982.

5) Fujita, K., Yamamoto, T., Yokota, T. and Kitagawa, R.: In vitro adherence of type 1fimbriated uropathogenic Escherichia coli to human ureteral mucosa. Infect. Immun., 57, 2574-2579, 1989.

6）那須良次：尿路性器感染症に打ける E. coli の病

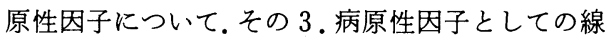
毛の尿路臟器特異性. 日泌尿会誌, 79, 1177-1186, 1988.

7) Virkola, R., Westerlund, B., Holthöfer, H., Parkkinen, J., Kekomäki, M. and Korhonen, T. K. : Binding characteristics of Escherichia coli adhesins in human urinary bladder. Infect. Immun., 56わ2615-2622, 1988.

8) Kisielius, P.V., Scwan, W.R., Amundsen, S.K., Duncan, J.L. and Schaeffer, A.J.: In vivo expression and variation of Escherichia coli type 1 and $P$ pill in urine of adults with acute urinary infections. Infect. Immun., 57, 1656-1662, 1989.

9) Doeling, K.J., Roberts, J. and Phd, M.B.K.: P-fimbriated Escherichia coli urinary tract infection: A clinical correlation. South. Med. J.,
80, 1533-1536, 1987.

10）山田大介：細菌性前立腺炎の発症に関する臨床細 菌学的研究. I. 臨床分離菌分布々前立腺液中細菌 特異抗体価. 日泌尿会誌，81，1458-1465, 1990.

11) Parkkinen, J., Finne, J., Achtman, M., Väisänenn, V. and Korhonen, T.K.: Escherichia coli strains binding neuraminyl ( $\alpha$ 2-3) galactosides. biochem. And biophys. Res. Commun., 111, 456-461, 1983.

12）那須良次, 山田大介, 小沢秀夫, 西村元一, 林 俊 秀, 牧 佳男, 藤本博志, 西谷嘉夫, 桜本耕司, 津 川昌也, 岸 幹雄, 水野全裕, 公文裕已, 大森弘之： 尿路感染症の年次的変遷と化学療法剂の関連性に ついて. 西日泌尿, 50，557-566， 1988.

13) Aumüller, G. : Über sialomucin produzierende Zellen der Prostata. Verh. Anat. Ges., 67S, 233-243, 1973.

14）欄 芳郎, 北村裕和, 山田和順：ヒト前立腺に括け る糖質の組織化学的研究. 解剖誌, 55, 253, 1980.

15) Parkkinen, J., Virkola, R. and Korhonen, T.K.: Identification of factors in human urine that inhibit the binding of Escherichia coli adhesins. Infect. Immun., 56, 2623-2630, 1988.

（1990年 6 月 14 日受理，特別掲載） 